\title{
Marzoan, Hamidi | Permainan Tradisional PERMAINAN TRADISIONAL SEBAGAI KEGIATAN EKSTRAKURIKULER UNTUK MENINGKATKAN KOMPETENSI SOSIAL SISWA
}

\author{
Marzoan, Hamidi \\ marzoanswandy@gmail.com \\ STKIP Hamzar Lombok Utara
}

\begin{abstract}
Abstrak
Penelitian ini bertujuan untuk menguji apakah penerapan permainan tradisional melalui program ekstrakurikuler dapat meningkatkan kompetensi sosial siswa di sekolah dasar. Dalam penelitian ini, permainan tradisional yang akan dimainkan adalah permainan yang umum dilakukan oleh masyarakat di daerah sekitar sekolah, yaitu permainan bentengan dan selodor. Kedua jenis permainan tradisional ini diasumsikan memiliki nilai kompetensi sosial karena dilakukan secara berkelompok yang memerlukan kerjasama. Desain eksperimen yang digunakan dalam penelitian ini adalah dengan desain pretest-postest control group design, yaitu desain eksperimen yang membagi subjek ke dalam kelompok eksperimen dan kelompok kontrol. Teknik analisis data dalam penelitian ini terbagi atas dua tahapan, tahap pertama menggunakan uji Wilcoxon, tahap kedua uji MannWithney $U$ Test. Subjek penelitian ini adalah 40 orang siswa SD di Kabupaten Lombok Utara yang terbagi dalam dua kelompok, yaitu 20 orang di SD Negeri 4 Gondang sebagai kelas eksperimen dan 20 orang siswa di SD Negeri 1 Rempek sebagai kelas kontrol. Kompetensi sosial dalam penelitian ini diukur dengan menggunakan skala kompetensi sosial. Hasil penelitian ini adalah (1) Terdapat perbedaan kompetensi sosial yang signifikan pada kelompok eksperimen antara sebelum dan sesudah diberi perlakuan; (2) Terdapat perbedaan kompetensi sosial yang signifikan antara kelompok eksperimen dan kelompok kontrol sesudah diberi perlakuan.
\end{abstract}

Kata Kunci : Permainan tradisional, ekstrakurikuler dan kompetensi sosial 


\section{Marzoan, Hamidi | Permainan Tradisional}

Abstract

This study aims to improve the ability of students in extracurricular programs to improve the social competence of students in primary schools. In this study, the traditional game to be played is a common game performed by the people in the area around the school, the game of fort and selodor. Both types of traditional games are assumed to have a social interest because it is done in groups that require cooperation. The experimental design used in this study was to design the pretest-posttest control group design, ie experimental design divided into experimental and control groups. Data analysis techniques in this study divided into two stages, the first stage uses the Wilcoxon test, the second stage of the Mann-Withney U Test. The subjects of this study were 40 elementary students in North Lombok Regency divided into two groups, namely 20 people in SD Negeri 4 Gondang as an experimental class and 20 students in SD Negeri 1 Rempek as control class. The social competence in this study is measured by using the scale of social competence. The results of this study were (1) There is a significant difference in social competence in the experimental group between before and after being treated; (2) There were significant differences in social competence between the experimental group and the control group after being treated.

Keywords : traditional games, extracurricular and social competence

\section{Pendahuluan}

Sekolah merupakan satuan pendidikan yang memiliki fungsi mendasar, sebagai wahana atau tempat berlangsungnya proses pembelajaran, proses penanaman dan pengembangan potensi-potensi individu. Sekolah adalah lembaga yang bersifat kompleks dan merupakan suatu sistem sosial yang di dalamnya terdapat berbagai dimensi yang saling berkaitan satu sama lain (Wahjosumidjo, 2011). Sekolah merupakan tempat menuntut ilmu pengetahuan dan wadah untuk mengembangkan keterampilan dan insitusi dalam proses perubahan sikap dan perilaku peserta didik. Sekolah merupakan lembaga pembudayaan menuju manusia berbudaya, berkarya dan karsa, sehingga output dari sekolah adalah sumber daya manusia yang berkualitas dan berkarakter (Isjoni, 2006). Sebagai bentuk 


\section{Marzoan, Hamidi | Permainan Tradisional}

tanggung jawab sekolah untuk mengembangkan kompetensi sosial siswa, maka sekolah harus kreatif mendesain proses pembelajaran maupun maupun memprogram kegiatan yang dapat meningkatkan komptensi sosial siswa.

Kompetensi sosial merupakan kemampuan individu merencanakan strategi untuk berinteraksi dengan orang lain dalam realitas perubahan sosial yang terjadi di sekelilingnya (Priamikova, 2010). Dewasa ini, masalah kompetensi sosial siswa masih menjadi tantangan besar lembaga pendidikan. Syaodih (2009) menyebutkan bahwa krisis pada aspek sosial sudah sampai pada bentuk yang cukup memprihatinkan. Pada kalangan siswa sekolah dasar dan menengah, seperti juga masyarakat pada umumnya gejala masalah sosial ini tampak dalam perilaku keseharian. Sikap-sikap individualistis, egoistis, acuh tak acuh, kurangnya rasa tanggung jawab, malas berkomunikasi dan berinteraksi atau rendahnya empati merupakan fenomena yang menunjukkan adanya kehampaan nilai sosial dalam kehidupan sehari-hari.

Kompetensi sosial dan kemampuan penyesuaian diri menjadi semakin penting dan krusial manakala anak sudah menginjak masa remaja. Hal ini disebabkan karena pada masa remaja individu sudah memasuki dunia pergaulan yang lebih luas, pengaruh teman-teman dan lingkungan sosial akan sangat menentukan. Kegagalan remaja dalam menguasai keterampilanketerampilan sosial akan menyebabkan dia sulit menyesuaikan diri dengan lingkungan sekitarnya sehingga dapat menyebabkan rasa rendah diri, dikucilkan dari pergaulan, cenderung berperilaku yang kurang normatif (misalnya asosial ataupun anti sosial), dan bahkan dalam perkembangan yang lebih ekstrim bisa menyebabkan terjadinya gangguan jiwa, kenakalan remaja, tindakan kriminal, tindakan kekerasan, dan sebagainya (Mu'tadin, 2002).

Dewasa ini, agen-agen sosialisasi yang berpengaruh terhadap perkembangan sosial tidak hanya keluarga dan sekolah, melainkan televisi dan video games juga menjadi agen penting 


\section{Marzoan, Hamidi | Permainan Tradisional}

yang mempengaruhi perkembangan sosial anak. Hal ini menandakan bahwa budaya sekarang yang banyak didominasi oleh teknologi digital turut memberi sumbangan terhadap perkembangan anak. Perolehan kemampuan sosial anak dari agen-agen yang serba instan dan kurang memperhatikan nilainilai edukasi akan mengarah kepada terbentuknya kompetensi sosial yang juga instan (Iswinarti, 2012).

Salah satu faktor yang dapat mempengaruhi kompetensi sosial yaitu partisipasi sosial. Kompetensi sosial dapat ditingkatkan dengan mendorong anak untuk berpartisipasi dalam lingkungan sosialnya. Santrock (2010) menjelaskan bahwa partisipasi sosial anak dalam suatu kelompok sosial akan memenuhi kebutuhan atas hubungan dekat dan kebersamaan. Keterlibatan seorang anak dalam suatu kelompok sosial formal maupun informal akan membantu anak melatih kemampuan dalam menjalin hubungan yang hangat. Partisipasi sosial secara informal pada anak dapat dilakukan dengan melibatkan anak dalam kegiatan bermain bersama teman sebayanya. Menurut Hurlock (1993) pola permainan yang dapat mendukung perkembangan sosial anak adalah pola permainan yang bernuansa sosial, yaitu pola permainan yang melibatkan interaksi dengan teman-teman sebaya.

Suasana seperti yang disebutkan Hurlock di atas dapat ditemui dalam permainan tradisional. Sebab, salah satu ciri yang menonjol dari permainan tradisional adalah dilakukan oleh dua orang atau lebih secara bertatap muka, keadaan ini memungkinkan anak untuk berinteraksi dengan teman bermainnya. Saat memainkan permainan tradisional, anak-anak diajak untuk berkumpul dan mengenal teman sepermainannya. Permainan tradisional dapat memberikan alternatif yang berbeda dalam kehidupan anak. Ariani (1998) menyebutkan bahwa ada beberapa nilai yang terkandung dalam permainan tradisional yang dapat ditanamkan dalam diri anak antara lain rasa senang, adanya rasa bebas, rasa berteman, rasa demokrasi, penuh tanggung jawab, rasa patuh dan rasa saling membantu yang 


\section{Marzoan, Hamidi | Permainan Tradisional}

kesemuanya merupakan nilai-nilai yang sangat baik dan berguna dalam kehidupan bermasyarakat.

Permainan tradisional merupakan permainan yang telah diturunkan dari satu generasi ke generasi (Bishop \& Curtis, 2001). Berbagai nilai luhur yang terkandung di dalam permainan tradisional menggambarkan bahwa permainan tradisional dapat digunakan sebagai media yang tepat untuk membentuk kepribadian anak. Hal ini relevan dengan hasil penelitian yang dilakukan Iswinarti (2012) yang menyebutkan bahwa gambaran tentang kandungan nilai-nilai pembelajaran kompetensi sosial pada permainan tradisional gembatan yaitu mencakup : (1) dalam komponen problem solving anak belajar mengatur strategi, mengambil keputusan dan sesolusi konflik; (2) dalam komponen pengendalian diri anak belajar mengikuti aturan, membedakan perilaku benar dan salah, serta mengekspresikan perasaan dengan tindakan yang tepat; (3) dalam komponen kerjasama, anak belajar berinteraksi positif dengan anak lain, berbagi gagasan/material, dan bekerja dengan anak lain dalam kelompok; (4) dalam komponen empati, anak belajar memahami perasaan, pandangan, dan kondisi anak lain, serta turut merasakan apa yang dialami oleh anak lain.

Penelitian tentang kontribusi permainan tradisional terhadap kompetensi sosial siswa telah dilakukan oleh beberapa peneliti, misalnya yang dilakukan oleh Wahyuni (2009) yang menemukan bahwa permainan tradisional gobag sodor terbukti dapat meningkatkan kualitas penyesuaian sosial anak sekolah dasar negeri Cakraningkratan Surakarta. Hasil penelitian Ferdiansyah (2009) juga mengungkap bahwa permainan betengan membantu perkembangan softskill anak sekolah dasar di Surabaya. Ferdiansyah menyebutkan bahwa permainan tradisional betengan memiliki sifat simple, aplikatif, dan memiliki efek yang besar sehingga sangat baik jika dilatih sejak usia anakanak. Dalam permainan tradisional betengan (jeg-jegan) terdapat 12 dari 20 softskill yang ada di dunia kerja, diantaranya kemampuan komunikasi, kejujuran dan integritas, kerjasama, 


\section{Marzoan, Hamidi | Permainan Tradisional}

ketrampilan, interpersonal, etika, motivasi dan inisiatif, kemampuan daya analitik, berorientasi pada detail, kepemimpinan, kepercayaan diri, kreativitas serta kemampuan beradaptasi. Penelitian Susanti (2010) juga menyimpulan bahwa kegiatan permainan tradisional memiliki pengaruh dalam meningkatkan kompetensi interpersonal anak sekolah dasar.

Mencermati berbagai pendapat di atas dapat diketahui bahwa permainan tradisional mempunyai nilai-nilai sosial dan psikologis yang tinggi. Namun demikian, dalam implementasinya permainan tradisional mengalami beberapa kendala seperti yang disebutkan oleh Bishop \& Curtis (2001) bahwa anak sekarang sudah tidak mengetahui lagi bagaimana cara bermain permainan teradisional. Kendala lain mengapa permainan tradisional sulit untuk diterapkan pada saat ini adalah karena tidak adanya pewarisan, tidak tersedianya lahan, dan anak lebih tertarik dengan permainan modern (Sedyawati, 1999).

Berdasarkan observasi awal dan wawancara dengan guru dan siswa di beberapa sekolah dasar di Kabupaten Lombok Utara, diketahui bahwa sejauh ini hampir semua sekolah belum pernah melaksanakan permainan tradisional kepada peserta didik melalui kegiatan ekstrakurikuler pramuka. Hal itu terjadi karena, sebagian guru dan guru pembina pramuka masih beranggapan bahwa permainan tradisional tidak perlu diprogramkan dalam kegiatan pramuka, karena sudah dilakukan atas inisiatif sendiri oleh siswa di lingkungan tempat tinggalnya. Sementara di satu sisi, sebagian besar siswa kelas IV dan kelas V yang diwawancarai mengaku tidak pernah memainkan permainan tradisional seperti bentengan dan selodor. Mencarmati uraian di atas, menarik untuk mengkaji lebih dalam mengenai bagaimana permainan tradisional yang merupakan warisan leluhur dapat dijadikan pilihan bagi sekolah sebagai salah satu kegiatan dalam program ekstrakurikuler pramuka sebagai upaya untuk meningkatkan kompetensi sosial siswa. 


\section{Marzoan, Hamidi | Permainan Tradisional Permainan Tradisional}

Permainan tradisional merupakan warisan antar generasi yang mempunyai makna simbolis di balik gerakan, ucapan, maupun alat-alat yang digunakan. Pesan-pesan tersebut bermanfaat bagi perkembangan motorik, kognitif, emosi dan sosial anak sebagai persiapan atau sarana belajar menuju kehidupan di masa dewasa (Suyadi, 2010). Permainan tradisional merupakan kegiatan yang dilakukan dengan suka rela dan menimbulkan kesenangan bagi pelakunya, diatur oleh peraturan permainan yang dijalankan berdasar tradisi turun-temurun. Akbari et al. (2009) menyebutkan bahwa permainan tradisional merupakan permainan yang mempunyai sejarah di daerah atau budaya tertentu yang di dalamnya mempunyai nilai-nilai kemanusiaan dan tidak merupakan hasil dari industrialisasi.

Permainan tradisional juga dikenal sebagai permainan rakyat merupakan sebuah kegiatan rekreatif yang tidak hanya bertujuan untuk menghibur diri, tetapi juga sebagai alat untuk memelihara hubungan dan kenyamanan sosial. Dalam hal ini, permainan merupakan alat bagi anak untuk menjelajahi dunianya, dari yang tidak dia ketahui sampai pada yang dia ketahui dan dari yang tidak dapat diperbuatnya, sampai mampu melakukannya. Dengan demikian dapat dikatakan bahwa bermain merupakan kebutuhan bagi anak. Oleh karena itu, diperlukan kemampuan merancang proses pembelajaran tertentu dengan mempertimbangkan unsur bermain yang sesui dengan taraf kemampuan anak. Jadi bermain bagi anak mempunyai nilai dan ciri yang penting dalam kemajuan perkembangan kehidupan sehari-hari termasuk dalam permainan tradisional (Mulyani, 2013).

Permainan tradisional dapat dikategorikan sebagai permainan sosial karena dimainkan oleh lebih dari satu orang. Menurut Dharmamulya (2008) nilai sosial yang terkandung dalam permainan tradisional adalah adanya interaksi sosial dalam kegiatan bermain. Beberapa ahli membuat beberapa klasifikasi permainan tradisional, seperti yang dikemukakan oleh Lavega 


\section{Marzoan, Hamidi | Permainan Tradisional}

(2007) yang membagi permainan tradisional menjadi empat kategori yang dalam kategori tersebut masih bisa dibedakan menjadi beberapa jenis permainan lagi. Keempat kategori tersebut adalah permainan psikomotor, permainan kerjasama, permainan yang mempunyai lawan dan permainan kerjasamaperlawanan. Dalam konteks penelitian ini, yaitu akan mengkaji dampak permainan tradisional terhadap kompetensi sosial siswa, maka kategori yang akan digunakan adalah kategori permainan kerjasama-perlawanan. Termasuk dalam kategori ini adalah permainan tardisional bentengan dan selodor.

Permainan tradisional benteng atau bentengan terdiri atas 4-8 orang. Permainan ini bertujuan untuk menyerang dan mengambil alih benteng lawan. Pada permainan ini, tiap-tiap anggota regu memiliki tugas antara lain sebagai penyerang, matamata, pengganggu, maupun penjaga benteng. Permaianan ini memerlukan kecepatan berlari dan kemampuan strategi yang tepat. Adapun permainan selodor dilakukan olah dua regu yang tiap-tiap regu terdiri atas enam orang atau lebih. Satu regu berperan sebagai penjaga, sementara regu lainnya berperan sebagai regu lawan. Inti permainan galasin adalah menghadang atau melakukan penjagaan terhadap lawan. Hal ini dilakukan agar lawan tidak dapat melewati garis hingga garis terakhir secara bolak balik. Regu yang anggotanya lengkap dapat melakukan proses bolah - balik dalam area lapangan yang telah ditentukan. Pemenang permainan ini adalah regu yang menyerang dengan semua pemain penyerang dapat kembali semua lengkap (Khamdani, 2010).

\section{Kegiatan Ekstrakurikuler}

Kegiatan ekstrakurikuler adalah kegiatan kurikuler yang dilakukan oleh peserta didik di luar jam belajar kegiatan intra kurikuler dan kegiatan kokurikuler, di bawah bimbingan dan pengawasan satuan pendidikan (Permendikbud Nomor 62, 2014). Pramuka merupakan kegiatan ekstrakurikuler yang wajib diselenggarakan oleh satuan pendidikan dan wajib diikuti oleh 


\section{Marzoan, Hamidi | Permainan Tradisional}

seluruh peserta didik. Oleh karena itu, kegiatan ekstrakurikuler yang dimaksud dalam penelitian adalah kegiatan ekstrakurikuler pramuka yang di dalamnya diprogramkan kegiatan permainan tradisional.

Disebutkan bahwa pengembangan berbagai bentuk kegiatan ekstrakurikuler dilakukan dengan mengacu pada prinsip partisipasi aktif dan menyenangkan. Prinsip ini sesuai dengan karakteristik anak usia sekolah dasar, yaitu : (1) mereka secara ilmiah memiliki rasa ingin tahu yang kuat dan tertarik pada dunia sekitar yang mengelilingi diri mereka sendiri, (2) mereka senang bermain dan lebih suka bergembira/riang, (3) mereka suka mengatur dirinya untuk menangai berbagai hal, mengeksplorasi suatu situasi dan mencobakan usaha-usaha baru, (4) mereka bergetar perasaannya dan terdorong untuk berprestasi sebagaimana mereka tidak suka mengalami ketidakpuasan dan menolak kegagalan-kegagalan, (5) mereka belajar secara efektif ketika mereka merasa puas dengan situasi yang terjadi, (6) mereka belajar dengan cara bekerja, mengobservasi, berinisiatif, dan mengajar anak-anak lainnya. (Sumantri, 2011).

Mencermati karakteristik anak usia sekolah dasar seperti disebutkan di atas, maka penting bagi sekolah untuk merancang sebuah kegiatan yang dapat memenuhi kebutuhan peserta didik terutama dalam hal menumbuhkan kompetensi sosial mereka melalui kegiatan bermain. Salah satu yang diasumsikan sesuai dengan hal tersebut adalah dengan memprogramkan permainan tradisional melalui kegiatan ekstrakurikuler pramuka di sekolah. Memprogramkan permainan tradisional dalam kegiatan ekstrakurikuler di sekolah dasar menjadi relevan dengan pertimbangan bahwa permainan tradisional memiliki banyak manfaat bagi anak, seperti mengasah kemampuan otak, kemampuan membuat strategi, sikap mudah bersosialisasi dan sebagainya. Selain karena permainan tradisional bisa menjadikan hiburan bagi anak, hal ini juga sekaligus berfungsi proses pelestarian budaya. 


\section{Marzoan, Hamidi | Permainan Tradisional}

Dalam realistasnya, upaya melestarikan permainan tradisional dalam program ekstrakurikuler di sekolah mendapat beberapa tantangan, misalnya, adanya larangan dari orang tua, sebagian orang tua takut anak-anak mereka terluka, kotor atau kulit anak menjadi terbakar matahari karena bermain di lapangan terbuka, akibatnya banyak orang tua yang lebih memilih untuk memberikan permainan yang bersifakt individual di ruangan tertutup. Faktor lain adalah faktor kesiapan pihak sekolah, baik menyangkut kemampuan guru dalam mempraktikkan permainan tradisional maupun dalam hal ketersediaan fasilitas pendukung permainan tradisional.

\section{Kompetensi Sosial}

Sukmadinata (2010) menyebutkan bahwa kompetensi mencakup semua kecakapan, kebisaan, keterampilan yang diperlukan seseorang dalam kehidupannya, baik sebagai pribadi, warga masyarakat, siswa dan karyawan (termasuk di dalamnya pimpinan). Kompetensi tersebut juga diartikan sebagai kemampuan peserta didik dalam bentuk pengetahuan, keterampilan, sikap dan nilai-nilai yang diwujudkan dalam kebiasan berpikir dan bertindak. Konsep kompetensi sosial banyak dirumuskan secara berbeda oleh para ahli, Gardner menyebutnya dengan intrapersonal, Gysbers mengistilahkannya dengan interpersonal skills, sementara Myrick menyebutnya dengan social skills. Dalam kehidupan masyarakat akhir-akhir ini kompetensi sosial diartikan sebagai kemampuan individu merencanakan strategi untuk berinteraksi dengan orang lain dalam realitas perubahan sosial yang terjadi di sekelilingnya (Priamikova, 2010).

Kompetensi sosial atau kecerdasan interpersonal menurut Jasmine (2007) di tampakkan pada kegembiraan berteman dan kesenangan dalam berbagai macam aktivitas sosial serta ketaknyamanan atau keengganan dalam kesendirian dan menyendiri. Orang yang memiliki jenis kecerdasan ini menyukai dan menikmati bekerja secara berkelompok (bekerja kelompok), belajar sambil berinteraksi dan bekerja sama, juga kerap merasa 


\section{Marzoan, Hamidi | Permainan Tradisional}

senang bertindak sebagai penengah atau mediator dalam perselisihan dan pertikaian baik di sekolah maupun di rumah. Sisi gelap kecerdasan interpersonal adalah tindak pencurangan atau penyelewengan, sedangkan sisi terangnya adalah empati. Kecerdasan ini milik orang ekstrovert.

Menurut Campbell (2004) kompetensi sosial yang umum, misalnya membentuk kelompok efektif, mendemonstrasikan tingkah laku yang pantas, menggunakan kompetensi belajar yang efektif, dan menilai serta mengevaluasi ide-ide secara bersamasama. Lebih jauh Campbell menyebutkan ciri-ciri orang yang memiliki kompetensi sosial yang bagus antara lain : (1) Terikat dengan orang tua dan berinteraksi dengan orang lain, (2) membentuk dan menjaga hubungan sosial, (3) Mengetahui dan menggunakan cara-cara yang beragam dalam berhubungan dengan orang lain, (4) Merasakan perasaan, pikiran, motivasi, tingkah laku, dan gaya hidup orang lain, (5) Berpartisipasi dalam kegiatan kolaboratif dan menerima bermacam peran yang perlu dilaksanakan oleh bawahan sampai pimpinan, dalam suatu usaha bersama, (6) Mempengaruhi pendapat dan perbuatan orang lain, (7) Memahami dan berkomunikasi secara efektif, baik dengan cara verbal maupun nonverbal, (8) Menyesuaikan diri terhadap lingkungan dan group yang berbeda dan juga umpan balik (feedback) dari orang lain, (9) Menerima perspkektif yang bermacam-macam dalam masalah sosial dan politik, (10) Mempelajari kompetensi yang berhubungan dengan penengah sengketa (mediator), berhubungan dengan mengorganisasikan orang untuk bekerjasama ataupun kerja sama dengan orang dari berbagai macam background dan usia, (11) Tertarik pada kair yang berorientasi interpersonal seperti mengajar, pekerjaan sosial, konseling, manajemen atau politik, (12) Membentuk proses sosial atau model yang baru.

Relevan dengan rumusan di atas, Sukartini (2005) menyebutkan bahwa yang dimaksud dengan kompetensi sosial adalah berkaitan dengan : (1) Empati, yaitu penuh pengertian, tenggang rasa, kepedulian pada sesama; (2) Afiliasi dan resolusi 


\section{Marzoan, Hamidi | Permainan Tradisional}

konflik, yaitu komunikasi dua arah/ hubungan antar pribadi, kerjasama, penyelesaian konflik; (3) Mengembangkan kebiasaan positif, seperti tata krama/kesopanan, kemandirian, dan tanggung jawab sosial. Kompetensi sosial adalah kemampuan untuk mengambil perspektif orang lain tentang situasi dan belajar dari pengalaman masa lalu, dan menerapkan pembelajaran dengan kondisi sosial yang dinamis. Kemampuan untuk merespon secara fleksibel dan tepat dalam mendefinisikan kemampuan seseorang untuk menangani tantangan sosial yang muncul. Kompetensi sosial anak merupakan fondasi yang mereka gunakan untuk mengembangkan persepsi perilaku mereka sendiri (Clikeman, 2007).

Proses pembentukan kompetensi sosial terjadi pada saat individu mengalami perkembangan sosial. Somantri (2007: 34) mengartikan perkembangan sosial yaitu dikuasainya kemampuan untuk bertingkah laku sesuai dengan tuntutan di masyarakat. Siswati (2010) menyebutkan bahwa anak yang dinilai tidak kompeten secara sosial cenderung mengalami penolakan atau isolasi sosial. Individu dapat mencapai kompetensi sosial jika memiliki keterampilan sosial yang kuat.

Menurut Iswinarti (2012) bahwa aspek kompetensi sosial yang digunakan dalam penelitian-penelitian tentang kompetensi sosial yang dijumpai seringkali tidak menggunakan konstruk tunggal. Aspek-aspek yang digunakan untuk melakukan pengukuran terhadap kompetensi sosial juga sangat bervariasi. Berdasarkan penelusuran literatur tentang konstruk maupun aspek yang digunakan dalam mengungkap kompetensi sosial ditemukan variasi yang sangat luas, namun Iswinarti merangkumnya menjadi empat, yaitu problem solving, pengendalian diri, kerjasama, dan empati. Dalam konteks penelitian ini aspek kompetensi sosial yang dipilih adalah kerjasama. Hal ini relevan dengan hasil penelitian Junttila et al (2012) yang menggunakan aspek kerjasama dan empati untuk mengukur kompetensi sosial dalam penelitiannya tentang kesepian pada anak usia sekolah, selain aspek impulsif dan 


\section{Marzoan, Hamidi | Permainan Tradisional}

desruptif. Kerjasama merupakan dasar bagi anak untuk berinteraksi sosial sehingga menjadi dasar bagi anak untuk dapat diterima oleh teman sebaya dan mengurangi resiko untuk ditolak (Bern, 2010).

Mulder (2008) menyebutkan bahwa kompetensi sosial anak dipengaruhi oleh faktor kepribadian atau karakteristik pribadi, lingkungan keluarga, meliputi ekonomi keluarga, saudara kandung, gaya pengasuhan, dan lingkungan sekolah meliputi hubungan guru dan siswa, interaksi anak dengan teman di dalam kelas, kurikulum sekolah, dan budaya dalam kelas. Adapun Zsolani (2002) menyebutkan bahwa faktor yang turut berperan terhadap kompetensi sosial anak adalah lingkungan sekolah. Sekolah mempunyai pengaruh yang besar terhadap perkembangan kompetensi sosial selama masa anak-anak. Lingkungan fisik di dalam kelas, struktur sosial kelas, dan budaya di dalam kelas saling berinteraksi dan berpengaruh terhadap kompetensi sosial anak.

\section{Metode Penelitian}

Desain eksperimen yang digunakan dalam penelitian ini adalah dengan desain pretest-postest control group design, yaitu desain eksperimen yang membagi subjek ke dalam kelompok eksperimen dan kelompok kontrol. Data diperoleh dari pretest dan posttest yang dilakukan di awal dan akhir penelitian untuk mengetahui tingkat kemajuan kelompok kontrol dan eksperimen. Variabel independen dalam penelitian ini adalah permainan tradisional, sedangkan variabel dependennya adalah kompetensi sosial siswa. Dalam penelitian ini siswa sebagai subjek penelitian, sedangkan penerapan permainan tradisional dalam program kegiatan ekstrakurikuler pramuka adalah perlakuan penelitian yang diberikan kepada subjek. Pengambilan sampel dalam penelitian ini dilakukan dengan menggunakan teknik purposive sampling.

Subjek Penelitian ini adalah 40 siswa kelas IV dan Kelas V SD di Kabupaten Lombok Utara, yang terbagi dalam dua sekolah 


\section{Marzoan, Hamidi | Permainan Tradisional}

yanitu 20 orang siswa di SD Negeri 4 Gondang dan 20 orang siswa di SD Negeri 1 Rempek Kecamatan Gangga Kabupaten Lombok Utara. Penelitian di awali dengan studi pendahuluan yang meliputi penyusunan dan pengembangan instrumen penelitian dan sharing dengan guru atau pembina pramuka terkait dengan kegiatan penelitian yang dilakukan. Instrumen yang dipersiapkan dalam hal ini adalah instrumen untuk mengetahui tingkat kompetensi sosial siswa. Disiapkan pula pedoma cara bermain permainan tradisional beserta alat dan bahan yang digunakan. Untuk mengetahui kemungkinan kendala yang muncul dalam kegiatan penelitian perlu dilakuka uji coba permainan tradisional, hal ini berfungsi untuk melatih guru/pembina dan siswa tentang bagaimana cara memainkan permainan tradisional bentengan dan selodoran.

Instrumen penelitian ini adalah tes kompetensi sosial yang sudah dikembangkan dan sudah divalidasi. Adapun tahapantahapan kegiatan yang akan dilakukan dalam pelaksanaan penelitian ini adalah : (1) memberikan pretes kompetensi sosial terhadap kedua kelompok kelas eksperimen dan kelas kontrol, (2) melaksanakan permainan tradisional pada program ekstrakurikuler sesuai dengan waktu yang sudah ditentukan, (3) melakukan pengamatan, dan (5) melakukan postest.

Kegiatan pengumpulan data mencakup dua tahap, yaitu : (1) Tahap persiapan, meliputi : studi pendahuluan, penyusunan perangkat permainan tradisional yang akan diimplementasikan, instrumen penelitian, dan uji coba permainan tradisional; (2) Tahap pelaksanaan, meliputi : memberikan pretest, melaksanakan perlakuan (treatment), dan memberikan postest. Teknik analisis data dalam penelitian ini terbagi atas dua tahapan, tahap pertama untuk uji statistik nonparametrik yang digunakan untuk menguji hipotesis pertama adalah dengan menggunakan uji Wilcoxon untuk dua sampel berhubungan. Tahap kedua untuk menguji hipotesis kedua adalah dengan uji Mann-Withney $U$ Test untuk dua sampel berpasangan. Analisa data uji hipotesis dalam penelitian ini menggunakan bantuan program SPSS for windows. 


\section{Marzoan, Hamidi | Permainan Tradisional Hasil Dan Pembahasan}

Hasil penelitian ini merupakan hasil analisis data yang dilakukan terhadap hipotesis penelitian. Hipotesis yang diuji dalam penelitian ini adalah sebagai berikut : (1) Terdapat perbedaan kompetensi sosial yang signifikan pada kelompok eksperimen antara sebelum dan sesudah diberi perlakuan; (2) Terdapat perbedaan kompetensi sosial yang signifikan antara kelompok eksperimen dan kelompok kontrol sesudah diberi perlakuan. Untuk hipotesis pertama yaitu untuk menguji perbedaan kompetensi sosial pada kelompok eksperimen antara sebelum dan sesudah diberi perlakuan dalam penelitian ini menggunakan uji Wilcoxon.

Hasil perhitungan dengan bantuan program SPSS dengan teknik analisis uji Wilcoxon disajikan dalam Tabel 1.1 berikut ini.

Tabel 1.1 Hasil Uji Wilcoxon

\begin{tabular}{|c|c|c|c|c|}
\hline \multicolumn{5}{|c|}{ Ranks } \\
\hline & & $\mathrm{N}$ & $\begin{array}{l}\text { Mean } \\
\text { Rank }\end{array}$ & $\begin{array}{l}\text { Sum of } \\
\text { Ranks }\end{array}$ \\
\hline \multirow{4}{*}{ Postest-Pretest } & $\begin{array}{l}\text { Negative } \\
\text { Ranks }\end{array}$ & $0^{\mathrm{a}}$ & ,00 & 00 \\
\hline & $\begin{array}{l}\text { Positive } \\
\text { Ranks }\end{array}$ & $16^{b}$ & 8,50 & 136,00 \\
\hline & Ties & $4^{c}$ & & \\
\hline & Total & 20 & & \\
\hline \multicolumn{5}{|c|}{ a. Postest $<$ Pretest } \\
\hline \multicolumn{5}{|c|}{ b. Postest $>$ Pretest } \\
\hline c. Postest $=$ Pretes & & & & \\
\hline
\end{tabular}

\begin{tabular}{lr}
\hline \multicolumn{2}{c}{ Test Statistics $^{\mathbf{a}}$} \\
\hline$Z$ & Postest - Pretest \\
\hline Asymp. Sig. (2-tailed) & $-3,581^{\mathrm{b}}$ \\
\hline a. Wilcoxon Signed Ranks Test &, 000 \\
\hline b. Based on negative ranks. & \\
\hline
\end{tabular}




\section{Marzoan, Hamidi | Permainan Tradisional}

Merujuk hasil uji pada kolom Ranks diketahui bahwa skor Negative Ranks atau selisih (negatif) kompetensi sosial untuk pretest dan postest adalah 0, baik itu pada skor N, Mean Rank, maupun Sum of Ranks. Nilai 0 ini menunjukkan tidak adanya penurunan (pengurangan) dari nilai pretest ke nilai postest. Positive Ranks atau selisih (positif) kompetensi sosial antara pretest dan postest, diketahui terdapat skor $\mathrm{N}=16$, artinya terdapat 16 orang siswa mengalami peningkatan kompetensi sosial. Mean Rank atau rata-rata peningkatannya mencapai 8,50 dan jumlah rangking positif atau Sum of Ranks sebesar 136,00. Ties adalah kesamaan nilai kompetensi sosial, hasil pengujian menunjukkan skor Ties $=4$, artinya bahwa ada empat orang siswa yang nilai kompetensi sosialnya sama.

Dalam uji hipotesis digunakan kolom kedua yaitu kolom Test Statistics ${ }^{a}$. Dasar pengambilan keputusannya adalah apabila nilai Asymp. Sig. (2-tailed) lebih kecil dari < 0,05, maka Ha diterima. Sebaliknya bila Asymp. Sig. (2-tailed) lebih besar dari > 0,05, maka Ha ditolak. Berdasarkan output Test Statistics ${ }^{a}$ di atas diketahui bahwa skor Asymp. Sig. (2-tailed) adalah =0,000. Skor ini lebih kecil dari $<0,05$. Maka dapat disimpulkan Ha diterima. Artinya, terdapat perbedaan kompetensi sosial siswa untuk pretest dan postets, sehingga dapat disimpulkan bahwa ada perbedaan kompetensi sosial kelompok siswa pada kegiatan ekstrakurikukler pramuka sebelum disertai permainan tradisional dengan sesudah disertai permainan tradisional.

Hipotesis kedua dalam penelitian ini adalah terdapat perbedaan kompetensi sosial kelompok siswa yang mengikuti kegiatan ekstrakurikuler pramuka yang disertai dengan permainan tradisional dengan kelompok siswa yang mengikuti kegiatan ekstrakurikuler pramuka tanpa disertai dengan permainan tradisional. Untuk uji hipotesis kedua ini menggunakan uji Mann-Withney U Test. Merujuk hasil pengujian uji Mann-Withney U Test diketahui bahwa skor Asymp. Sig. (2tailed) sebesar 0,004, skor ini lebih kecil dari 0,05. Dengan dasar pengambilan keputusan bahwa apabila signifikansi atau Asymp. 


\section{Marzoan, Hamidi | Permainan Tradisional}

Sig. (2-tailed) lebih kecil dari probabilitas 0,05, hipotesis diterima, maka hasil uji ini menunjukkan hipotesis diterima.

Dengan diterimanya hipotesis maka dapat diartikan bahwa terdapat perbedaan komptensi sosial antara kelas eksperimen dan kelas kontrol setelah diberikan perlakuan dengan permainan tradisional. Perbedaan kompetensi sosial ini juga dapat diketahui dari skor Mean Rank pada output tabel SPSS di atas. Diketahui bahwa skor untuk kelas eksperimen adalah 25,70, sementara untuk kelas kontrol sebesar 15,30. Berdasarkan hasil pengujian ini, dapat disimpulkan bahwa kompetensi sosial siswa yang mengikuti kegiatan pramuka yang disertai dengan permainan tradisional memiliki kompetensi sosial yang lebih baik bila dibandingkan dengan kelompok siswa yang tidak menggunakan permainan tradisional dalam ektrakurikuler.

Temuan penelitian ini memperkuat hasil kajian yang dilakukan Iswinarti (2012) yang menyatakan bahwa ada korelasi antara bermain dan kompetensi sosial meskipun korelasinya tidak selalu positif. Terjadinya korelasi positif maupun negatif antara bermain dan kompetensi sosial dapat sangat tergantung pada jenis permainan apa yang dimainkan. Permainan yang tergolong dalam kategori bermain sosial adalah permainan yang membutuhkan kerjasama dengan berkelompok atau permainan dengan aturan. Beberapa hasil penelitian yang lain juga menyimpulkan bahwa bermain sosial berkorelasi positif dengan kompetensi sosial sedangkan bermain sendiri (solitary play) berkorelasi negatif dengan kompetensi sosial. Mengingat bermain bentengan dan selodoran merupakan permainan tradisional yang dimainkan dengan cara berkelompok, yang membutuhkan kerjsama dan memiliki aturan, maka hasil penelitian ini sejalan dengan beberapa hasil penelitian terdahulu, yaitu permainan tradisional bentengan dan selodoran dapat berkontribusi positif terhadap kompetensi sosial siswa. 


\section{Kesimpulan}

\section{Marzoan, Hamidi | Permainan Tradisional}

Berdasarkan pengolahan data dan hasil penelitian dapat disimpulkan sebagai berikut: (1) Terdapat perbedaan kompetensi sosial yang signifikan pada kelompok eksperimen antara sebelum dan sesudah diberi perlakuan. Kelompok eksperimen dalam penelitian ini adalah kelompok siswa yang diberikan perlakuan permainan tradisional dalam kegiatan ekstrakurikuler pramuka. Hasil analisa data menunjukkan bahwa ada perbedaan kompetensi sosial siswa antara sebelum dan sesudah mengikuti kegiatan ekstrakurikuler pramuka setelah diberikan perlakuan permainan tradisional; (2) Terdapat perbedaan kompetensi sosial yang signifikan antara kelompok eksperimen dan kelompok kontrol sesudah diberi perlakuan. Kelompok kontrol dalam penelitian ini adalah kelompok siswa yang mengikuti kegiatan ekstrakurikuler pramuka tanpa disertai permainan tradisional. Sebelum diberikan perlakuan permainan tradisional, kompetensi sosial siswa antara kelompok eksperimen dan kelompok kontrol relatif sama, namun setelah diberikan perlakuan permainan tradisional, kompetensi sosial kelompok eksperimen lebih baik bila dibandingkan dengan kelompok kontrol. 


\section{Marzoan, Hamidi | Permainan Tradisional}

\section{DAFTAR PUSTAKA}

Akbari, A. (2009). The effect of Traditional Games in Fundamental Motor Skill Development in 7-9 year olds Boy. (onlie) http://Iran J Pediatr.org.

Ariani, C. (1998). Pembinaan Nilai Budaya Melalui Permainan Rakyat Daerah Istimewa Yogyakarta. Yogyakarta: Depdikbud, Dirjen Kebudayaan, Direktorat Sejarah dan Nilai Tradisional

Berns, R. M. (2010). Child, family, school, community: Socialization and support. 8th edition. United States of America: Wadworth, Cengage Learning.

Bishop, J. C., \& Curtis, M. (2001). Play today in the primary school playground: Life, learning, and creativity. Buchingham: Open University Press

Campbell, Linda, et al. (2004) Metode Praktis Pembelajaran Berbasis Multiple Intelligences. Jakarta : Intuisi Pers.

Clikeman \& Margeret S. (2007). Social Competence In Childern. New York: Springer Science+Business Media

Dharmamulya, S. (2008). Permainan Tradisional Jawa. Yogyakarta: Kepel Press.

Hurlock, E.B. (1993). Perkembangan anak jilid I. Terjemahan. Jakarta: Penerbit Erlangga.

Isjoni. (2006). Pendidikan Sebagai Investasi Masa Depan. Jakarta: Yayasan Obor Indonesia

Iswinarti. (2015). Permainan Tradisional Gembatan dan Kompetensi Sosial Anak Usia Sekolah. Proceeding Asean Conference 2nd Psychology \& Hummanity. UMM. Malang.

Iswinarti. (2012). Nilai-nilai pembelajaran kompetensi sosial pada permainan tradisional untuk anak usia sekolah. Presentasi paper dalam National Conference Fakultas Psikologi Ubaya : Surabaya.

Jasmine, Julia. (2007). Mengajar dengan Metode Kecerdasan Majemuk. Implementasi Multiple Intelegences. Bandung. Nuansa.

Junttila, N., Vauras, M, Niemi, P. M. \& Laakkonen, E. (2012) .Multisource assessed social competence as a predictor for children's and adolescents' later loneliness, social anxiety, and social phobia. Journal for Educational Research Online Journal für Bildungsforschung Online, 4(1), 73-98 


\section{Marzoan, Hamidi | Permainan Tradisional}

Khamdani \& Ajun. (2010). Olahraga Tradisional Indonesia. Singkawang: PT. Maraga Borneo Tarigas.

Lavega, P. (2007). Traditional games in Spain: A social school of values and learning. http://www.atsga.com/pdf/Traditional_Games_in_Spain_L avega.pdf.

Mulder, S. (2008). The domains that influence the development of social competence in children: A literature review. A Research Paper. Master of Science Degree in School Psychology, University of Wisconsin-Stout

Mulyati, S. (2013). Permainan Tradisional Anak Indonesia, Yogyakarta: Langensari Publising

Mu'tadin \& Zainun. (2002). Mengembangkan Ketrampilan Sosial pada Remaja. [Online]. Tersedia :http://www.epsikologi.com.

Priamikova, E. V. (2010). The social competence of school students. Russian Education and society, 52(6), 21-34.

Santrock, J.W. (2010). Educational Psycology, Edisi 5. Dallas : McGraw-Hill Company, Inc.

Sedyawati, E. (1999). Permainan Anak-anak sebagai Aspek Budaya. Editor : Krisdiyatmiko. Dolanan Anak : Refleksi Budaya dan Wahana Tumbuhkembang Anak. Yogyakarta : Plan International Indonesia-Yogyakarta dan LPM Sosiatri Fisifol UGM.

Siswati \& Novita. (2010). Pengaruh Social Stories Terhadap Keterampilan Sosial Anak dengan Attention-Deficit Hyperactivity Disorder (Adhd). Jurnal Psikologi Undip. 2(II). Hlm. 102.

Somantri \& Sutjihati. (2007). Psikologi Anak Luar Biasa. PT. Refika Aditama: Bandung

Sukartini S., P, (2005). Model Konseling Keterampilan Hidup Untuk Mengembangkan Karakteristik Pribadi yang Tegar. Disertasi, Bandung: FPS UPI Bandung. Tidak diterbitkan.

Sukmadinata, N.S. (2010). Landasan Psikologi Proses Pendidikan. Bandung : Remaja Rosdakarya.

Susanti, Fitria \& Siswati. (2010) Pengaruh Permainan Tradisonal terhadap Kompetensi Interpersonal dengan Teman Sebaya pada Siswa SD (Studi Eksperimental pada Siswa Kelas 3 SDN Srondol Wetan 04-09 dan SDN Srondol Wetan 05-08 ). Jurnal Psikologi Undip Vol. 8, No.2, 145-155.

Suyadi. (2010). Psikologi Belajar PAUD. Yogyakarta : Pedagogia 


\section{Marzoan, Hamidi | Permainan Tradisional}

Syaodih \& Erliany. (2009). Pengembangan Model Pembelajaran Kooperatif untuk Meningkatkan Keterampilan Sosial. [Online]. Tersedia : http://educare.e-fkipunla.net

Taufik. (2011). Managing Diversity as synergy : Increasing ethnoculural empathy by the traditional games of javanies and chinese in Indonesia (Unpublished doctoral dissertation). Tilburg University, Dutch.

Tuckman, BW. (1999). Cunducting Educational Research. 5th Edition. Orlando : Harcourt Brace College Publisher.

Wahjosumidjo. (2011). Kepemimpinan Kepala Sekolah Tinjauan Teoritik dan Permasalahannya. Jakarta: Raja Grafindo Persada.

Zsolani, A. (2002). Relationship between children social competence, learning motivation, and school achievement. Educational Psychology, 22(3), 317-329 